\title{
Nicolai Graakjær \& Christian Jantzen (Eds.): Music in advertising. Commercial sounds in media communication and other settings. Aalborg: Aalborg University Press. 2009
}

\section{Ola Stockfelt}

MedieKultur 2010, 48, 145-147

Published by SMID | Society of Media researchers In Denmark | www.smid.dk The online version of this text can be found open access at www.mediekultur.dk

It is a rather common understanding that very little research has been done on music in advertising. While this is actually not completely true, so far it still remains a fact that research into music and advertising from the perspectives of, e.g., economy or media studies is almost never combined with research into music and advertising from musicological perspectives in spite of the fact that this is an area where both perspectives are obviously relevant. Thus, it is especially gratifying to read a volume in an internationally accessible language where these perspectives are combined in a complementary fashion - a book that can function as an introduction to the field of study and as a statement and a demonstration to researchers in both fields of what the research can gain from a somewhat joint approach.

The major corpus of the anthology consists of results and spinoffs from Nicolas Graakjær's dissertation (Musik i tv-reklamer. En tekstanalytisk undersøgelse, Aalborg 2008), which have been translated into English as a number of separate essays, edited for accessibility for a wider audience and with the results and discussions presented in the dissertation occasionally further developed and contextualised. Making these results available for the wider research community outside the Nordic countries is definitely a valuable contribution as such, and is in itself sufficient motivation for the book. Between the chapters related to the results from this dissertation, new texts from a number of other researchers have been interfoliated, thus widening the scope of the work, presenting a variety of complementary and contrasting approaches to the field of study and providing the reader with a number of penetrating analyses and case studies. 
The very first chapter, "Mapping research on music in TV commercials", is a succinct answer to the general claim made in most earlier publications of research on the uses and functions of music in TV commercials that there is a profound lack of earlier studies of music in TV commercials. By presenting a 40 page thematically structured overview of studies that have been published earlier in the English, German and Nordic languages, authors Graakjær and Jantzen not only refute this claim - they also establish a level of disciplinary contextuality that ought to ensure that studies in this field, at least in these languages, need never again start from scratch.

In the following chapter, Graakjær provides a follow-up by using results from some of these previous studies as well as his own to outline a form of categorisation of different ways music appears in television commercials, in local/regional, national and international media, and to spot diachronic tendencies between the different categories. Matthias Bode provides a compelling argumentation against the methodological failures and general disregard of the actual music in traditional advertising research on music, and also provides a very constructive attempt to rectify the situation by presenting usable categories and models for further studies of the salient possible relations between different kinds of music and commercials.

Graakjær, Erkki Pekkilä and Anders Bonde, each in separate essays, provide different types of close readings of various "texts" - use of pre-existing music as a music brand, as in the case of the Jutlandish "Jysk" jingle, relationships between music videos and commercials related to the same tune and artist, as in Steve Winwoods "what the night can do" and a commercial for a beer brand, the use of Shostakovich's "Waltz № 2" in a Kubrick film, a Danish TV documentary and a commercial for a bank - thus in each case providing good and insightful examples of what research and analysis in this area in fact can gain from a closer study of the actual music.

Graakjær and Jantzen then shift the perspective and focus on various types of commercial and promotional use of music for "hidden advertising" on the part of TV programming that is usually not regarded as commercials, thus both problematising the borders between advertising, product placement, sponsored and/or out-sourced programmes and channel profiles, and highlighting the fact that the music that is an integral part of most TV programmes is also a marketable commodity in itself. In the following short essay, the same two authors take on music's functions also in the flow of TV programming between the actual programmes.

While the early parts of the book deal primarily with music in TV, the final essays widen the perspective somewhat to other media and situations. Graakjær and Iben Jessen discuss the uses of music and sound on the web, and try to provide a basis for "an overview of typical functions of auditory phenomena in web advertising" (p. 195). While it might be quite a simplification to regard "web advertising as a genre" (p. 206), possibly even more so than to discuss, e.g., "film music" as a genre, there are still some relatively stable characteristics (e.g., Internet as a "pull" media) that are necessary to consider if results and methods from 
earlier research into music and advertising are to be successfully adapted to the web, and the authors provide a very constructive discussion on several of these. And considering the fact that "normal" television is being more and more utilized through the Internet as well, several of these considerations might very well soon (or already?) be crucial also for more "traditional" TV music commercial research.

Alf Björnberg discusses the use of music in Swedish radio commercials, providing both a short historical background, a useful typology of types of functions of music in this context, and a historical comparison that might provide clues for further development in the rapid ongoing media convergence. His conclusion that "a shorter attention span, but also a considerably higher degree of decoding competence, is expected on the part of the presentday listener" (p. 230) might definitely be valid far outside the realm of traditional radio programming.

Graakjær and Jantzen then in two essays take on the areas of music in shopping malls and stores, and the uses of music in corporate branding. The former essay is mainly a short overview based on, and in effect found in, numerous earlier studies, but it would of course have been unfortunate to omit presenting this area of research in a collection such as this. The latter consists of an interview with two nationally successful producers of corporate sounds, touching upon both the typologies involved, the aesthetic and commercial considerations and the actual production processes - a switch of perspective that illuminates the book as a whole in spite of the fact that the interview is left practically uncommented upon and un-analyzed by the authors.

In the book's concluding essay, Martin Knakkegard sets out to provide a preliminary discussion on the ontology of music and musical structures in film, in a manner that is occasionally thought provoking. He uses considerable effort to prove beyond any reasonable doubt that non-autonomous music is non-autonomous music, not genuine musical expressions, and seems to propagate a closer focus on what he designates non-film music. Still, the problems with his approach seem to be located mainly in the area of terminology, and when he gets into discussions of details in actual music, the discourse provides illuminating counterpoints to the three close-readings presented in the earlier part of the book.

As a whole, the book delivers exactly what its editors/authors explicitly aim for: it demonstrates how both advertising research and musicological research is necessary for the study of music in advertising, and in related commercial areas, and provides a solid basis for both joint and complementary studies into this very central and still under-researched field.

Ola Stockfelt

Associate Professor, Ph.D.

Department of Cultural Sciences

University of Gothenburg, Sweden ola.stockfelt@musicology.gu.se 